Article

\title{
Economic Feasibility of Managing Loblolly Pine Forests for Water Production under Climate Change in the Southeastern United States
}

\author{
Andres Susaeta ${ }^{1, *}$, Damian C. Adams ${ }^{1}$, Carlos Gonzalez-Benecke ${ }^{2}$ and José R. Soto ${ }^{1}$ \\ 1 School of Forest Resources and Conservation, University of Florida, P.O. Box 110410, Gainesville, FL 32611, \\ USA; dcadams@ufl.edu (D.C.A.); josesoto@ufl.edu (J.R.S.) \\ 2 Department of Forest Engineering, Resources and Management, Oregon State University, Corvallis, \\ OR 97331, USA; carlos.gonzalez@oregonstate.edu \\ * Correspondence: asusaeta@ufl.edu; Tel.: +1-352-846-0877; Fax: +1-352-856-1277
}

Academic Editor: Timothy A. Martin

Received: 19 January 2017; Accepted: 14 March 2017; Published: 16 March 2017

\begin{abstract}
In this study, we assessed the impacts of climate change, forest management, and different forest productivity conditions on the water yield and profitability of loblolly pine stands in the southeastern United States. Using the 3-PG (Physiological Processes Predicting Growth) model, we determined different climatic projections and then employed a stand level economic model that incorporates, for example, prices for timber and increased water yield. We found that, under changing climatic conditions, water yield increases with thinnings and low levels of tree planting density. On average, under moderate climatic conditions, water yield increases by $584 \mathrm{~kL} \cdot \mathrm{ha}^{-1}$ and $97 \mathrm{~kL} \cdot \mathrm{ha}^{-1}$ for low and high productivity conditions, respectively. Under extreme climatic conditions, water yield increases by $100 \mathrm{~kL} \cdot \mathrm{ha}^{-1}$ for low productivity conditions. Land expectation values increase by $96 \%$ ( $\$ 6653.7 \mathrm{ha}^{-1}$ ) and $95 \%\left(\$ 6424.1 \mathrm{ha}^{-1}\right.$ ) for each climatic scenario compared to those obtained for unthinned loblolly pine plantations managed only for timber production and under current climatic conditions. The contributions of payments for increased water yield to the land values were 38\% (\$2530.1 ha ${ }^{-1}$ ) and 30\% (\$1894.8 $\left.\mathrm{ha}^{-1}\right)$. Results suggest that payments for water yield may be a "win-win" strategy to sustainably improve water supply and the economic conditions of forest ownership in the region.
\end{abstract}

Keywords: water yield; loblolly pine; forest management; climate change; economic value

\section{Introduction}

The total United States (US) human-induced greenhouse gas emissions due to the burning of fossil fuels and land use changes reached 6870 million megagrams in 2014, representing a 7\% increase since 1990 [1]. These emissions are predicted to cause future warmer temperatures and changes in the precipitation patterns [2]. In the southern US, annual temperatures are expected to increase between 2.5 and $3.5^{\circ} \mathrm{C}$ by 2060 , while precipitation forecasts are highly variable across the region $[3,4]$. For example, the average precipitation change is expected to range between $-50 \%$ and $25 \%$, and $-35 \%$ and $15 \%$, in summertime and wintertime, respectively, for the period 2070-2090, compared to those levels of average precipitation between 1971-1999 [5].

Climate change can significantly alter the productivity of southern forest ecosystems. Increased levels of carbon dioxide and warmer temperatures are expected to stimulate forest growth $[6,7]$. Quinn Thomas and Ahlswede [8] reported that the aboveground net primary production for a 25 -year loblolly pine forest rotation would increase between $35 \%-60 \%$ under changing climatic conditions. However, the gains in forest growth can be offset if water becomes the limiting factor 
due to higher temperatures or prolonged droughts [9]. For example, Sun et al. [10] determined a 22\% and $15 \%$ reduction of the productivity of mid-rotation loblolly pine plantations when precipitation was reduced by $30 \%$ and $15 \%$, respectively. This reduction of forest productivity might be even more exacerbated with other climate change related effects such as fires, pest outbreaks, and other natural disturbances [11,12]. With the increasing public interest in climate change, the recent calibration of forest simulation models that estimate forest productivity under different climate scenarios [13] have become a powerful tool for forest landowners and managers to determine the optimal forest management regimes for commercial southern pines.

Southern forests cover around 100 million hectares [14], and play a pivotal role in the economy of the region by: (i) leading the total growing stock removal with 227 million cubic meters in 2008 (63\% of the Nation's total removals) [14]; (ii) supporting an industry that supplies $16 \%$ of the global industrial wood; and (iii) contributing $5.5 \%$ of the jobs and $7.5 \%$ of the industrial economic activity [15]. These forests have the potential to sequester $23 \%$ of the regional greenhouse gas emissions [16] and provide a clean source for aquatic habitat, drinking water, and groundwater recharge, supplying $34 \%$ of the regional water yield [9]. Changing climatic conditions can severely impact the economic and ecological value of these forests.

Different climate models have projected that water yield (the difference between precipitation and evapotranspiration) across the South will decrease $10 \mathrm{~mm}$ per decade until 2060 [17], driven by higher temperatures that increase evapotranspiration and decreased precipitation [18]. Generally, a $1 \%$ increase (decrease) in precipitation is expected to increase (decrease) water yield by $2 \%[19,20]$. From a forest-based water production perspective, a $2{ }^{\circ} \mathrm{C}$ increase in temperatures can decrease water yield by $11 \%$, and a $10 \%$ reduction of precipitation can lead to a $20 \%$ decline in water yield in loblolly pine forests [21]. These impacts can be magnified by land use change and forest disturbances that reduce the forest estate. The reduction of water yield combined with increased population and land use changes may increase water stress by $10 \%$ by 2050 across the South [9].

As such, forest practices such as thinnings, soil conservation, and targeted species selection are suggested as viable management strategies to increase water supply for downstream uses and for the forest itself [22]. Forest thinnings reduce leaf area and forest transpiration, thus the evapotranspiration is reduced and the water yield is increased [21]. Reported increased water yields after removal of basal area through thinnings range between $3 \%-64 \%$ depending on the forest species, age of the forest, location, and intensity of the thinnings $[21,23,24]$.

While there have been several studies assessing the impacts of forest stand management on water yield, the role of incentive payments in this context has been very limited. A notable exception is Susaeta et al. [25], who analyzed the economic tradeoffs between timber benefits and water yield in slash pine forest plantations in Florida, and concluded that up to $33 \%$ higher economic profits for landowners were obtained with conservatively low prices for water yield, increased planting density, and heavily thinned slash pine forests. However, this study neglected to consider the impacts of climate change on the forest based water yield, and the use of other sites with different climatic and forest characteristics were not considered. Other studies that have included payments for water yield without considering the effects of climate variability on water production are Creedy and Wurzbacher [26] who found that the value of forests in Australia increased, and the optimal harvest age can be lengthened (in some cases to infinity), with higher water values; and Bowes et al. [27] who determined that managing forests in Colorado is not an attractive economic option given the high access costs to these forests, unless timber is managed in conjunction with watershed augmentation programs Considering the key role that southern forests play in the water supply for the region-around 49 million people in the region receive their drinking supply from state and private forests [28], it is imperative that we determine the economic feasibility of forest management regimes that can meet the society's demand for water production under changing climatic conditions.

The main goal of this study was to analyze the impacts of climate change on water yield and optimal stand level management of loblolly pine (Pinus taeda L.) forests in the southeastern (SE) 
US. Loblolly pine is the main commercial, fast growing species in the SE US, planted on more than 10 million hectares (ha) [29]. Its native range extends from north Florida to south New Jersey and from east Texas to south Missouri [14,30]. We employed the semi-process based simulation model 3-PG (Physiological Processes Predicting Growth, [31] calibrated for loblolly pine [13]) to assess forest productivity under different climatic scenarios in three states in the SE US: Florida (FL), Georgia (GA), and South Carolina (SC). We selected the forest management schemes that increased loblolly pine based water yield and assessed the economic implications of payments for increased water yield on their land expectation values and optimal harvest ages. The reminder of the paper is as follows. In Section 2, we describe the stand level economic model of loblolly pine for timber and water production, the forest growth simulation model 3-PG, the climatic scenarios, forest management schemes, and economic parameters. We also describe the application of the model and the criteria to determine the feasibility of alternative loblolly pine management approaches for increased water yield. In Section 3, we present the findings of our study, which are discussed in Section 4. Finally, we offer concluding remarks.

\section{Materials and Methods}

\subsection{Economic Model Specification}

We determined the impact of payments for water yield on the optimal forest management of loblolly pine using the Hartmann model [32]. This model assumes that, in addition to timber production, the forest stand provides a flow of amenity benefits. In our study, we assumed increased water yield as the amenity service produced by a loblolly forest stand. Following Susaeta et al. [25], the land expectation value $\left(L E V ; \$ \mathrm{ha}^{-1}\right)$-the net present value timber $(F)$ and amenity benefits $(H)$ assuming forestry use in perpetuity—takes the following form:

$$
\begin{gathered}
L E V(T)=F+H \\
F=\frac{P V(T) e^{-r T}+\sum_{j}^{t} P_{t h} V_{t h}(j) e^{-r j}-\sum_{o}^{T} c(T) e^{-r T}}{1-e^{-r T}} ; H=\frac{\int_{0}^{T} G(s) e^{-r s} d s}{1-e^{-r T}} ; T>j ; T>t ; j>0
\end{gathered}
$$

where $P$ represent the stumpage price, $V(T)$ is the merchantable timber production at time $T ; P_{\text {th }}$ is the net price of thinned wood; $V_{\text {th }}$ is the amount of thinned timber at time $j ; \sum_{j}^{t} \mathrm{P}_{\text {th }} \mathrm{V}_{\text {th }}(j)$ represents the sum of thinnings revenues between times $j$ and $t ; c$ represents the forest management costs; $G(s)$ represent the monetary payments at time $s$ for increased water yield through silvicultural management; and $r$ is the discount rate. The time $T$ that maximizes $L E V$ is the optimal harvest age ( $T^{*}$ ). If $G$ is an increasing (decreasing) function of time $s$, the incorporation of payments for increased water yield can lengthen (shorten) the optimal harvest age $T^{*}$. A full detailed summary of the rule of harvesting and impacts of non-timber benefits can be found in Hartmann [32].

We assumed that the monetary benefits of increased water yield $G(s)$ results from the difference between the water yield between two forest management regimes. Thus, to calculate the increase of water yield we determined the difference in water yield between a forest management under changing climatic conditions $\left(W^{c c}\right)$ and a forest management under current climatic conditions $\left(W^{n c}\right)$-variation in water yield (in kL). Following McLaughlin et al. [23] and Susaeta et al. [25], we modelled, respectively, water yield $W$ for each forest management under each climatic regime, and the valuation function of increased water yield $G(s)$ :

$$
\begin{aligned}
& W=(1-E T / P P T) M P \\
& G(s)=P_{w}\left(W^{c c}-W^{n c}\right)
\end{aligned}
$$

where $E T / P P T$ is the ratio between evapotranspiration and precipitation, and $M P$ is the mean annual precipitation, and $P_{w}$ is the price of water production.

We employed the forest simulation model 3-PG (Physiological Processes Predicting Growth; Landsberg and Waring, [31] to determine the loblolly pine stand growth $(V(T))$ under changing 
climatic conditions. This model has been widely used to determine the impacts of management, site characteristics, and climate on stand productivity for different tree species [33-35]. The 3-PG model was parametrized and successfully tested from varying loblolly pine stand characteristics across the SE US [13]. The main inputs of 3-PG are weather data (temperatures, precipitation, number of rainy days, global radiation) and initial values of site characteristics such as soil texture, available soil water, and stand characteristics such as initial age, stand location, and initial stocking, among others [13]. A full description of the 3-PG model can be found in Landsberg and Waring [31] and Landsberg and Sands [36]. Furthermore, we employed the equations developed by Pienaar et al. [37] to determine the merchantable volume of three forest product classes: sawtimber (sw), chip-and-saw (cns), and pulpwood (pw), which were defined based on their quadratic mean diameter (Dq) and merchantable diameter limit: sw: $\mathrm{Dq}=29.2 \mathrm{~cm}$, top diameter $=17.8 \mathrm{~cm} ; \mathrm{cns}: \mathrm{Dq}=19.1 \mathrm{~cm}$, top diameter $=15.2 \mathrm{~cm}$; and pw: $\mathrm{Dq}=11.4 \mathrm{~cm}$, top diameter $=7.6 \mathrm{~cm}$.

\subsection{Climatic Scenarios}

For our economic modeling, we considered three climate change scenarios that included a range of feasible future climate conditions. For our baseline, we assumed no changes in climate and $\mathrm{CO}_{2}$ concentration. Alternatives included two representative concentration pathway (RCP) scenarios: low-to-medium greenhouse gas emissions (scenario RCP4.5), and high greenhouse gas emissions (scenario RCP8.5) [38]. For the baseline scenario, we fed the historical levels of precipitation and temperatures for the period 1950-2005 into the 3-PG model to simulate loblolly pine growth. For both alternative scenarios (RCP4.5 and RCP8.5), we employed the second generation CanESM2 (Canadian Earth system) model, downscaled using the Multivariate Adaptive Constructed Analogs (MACA) approach, to project future precipitation and temperatures [39] and simulate the growth of loblolly pine between 2050-2100 using 3-PG (Table 1). Thus, for each of the three climatic scenarios we simulated loblolly growth from planting to age 50 years on nine sites across three states in the SE US: Florida (FL), Georgia (GA), and South Carolina (SC) (Figure 1).

Table 1. Average precipitation $(\mathrm{Pp})$, maximum and minimum temperatures (tmax, tmin) for all climatic scenarios.

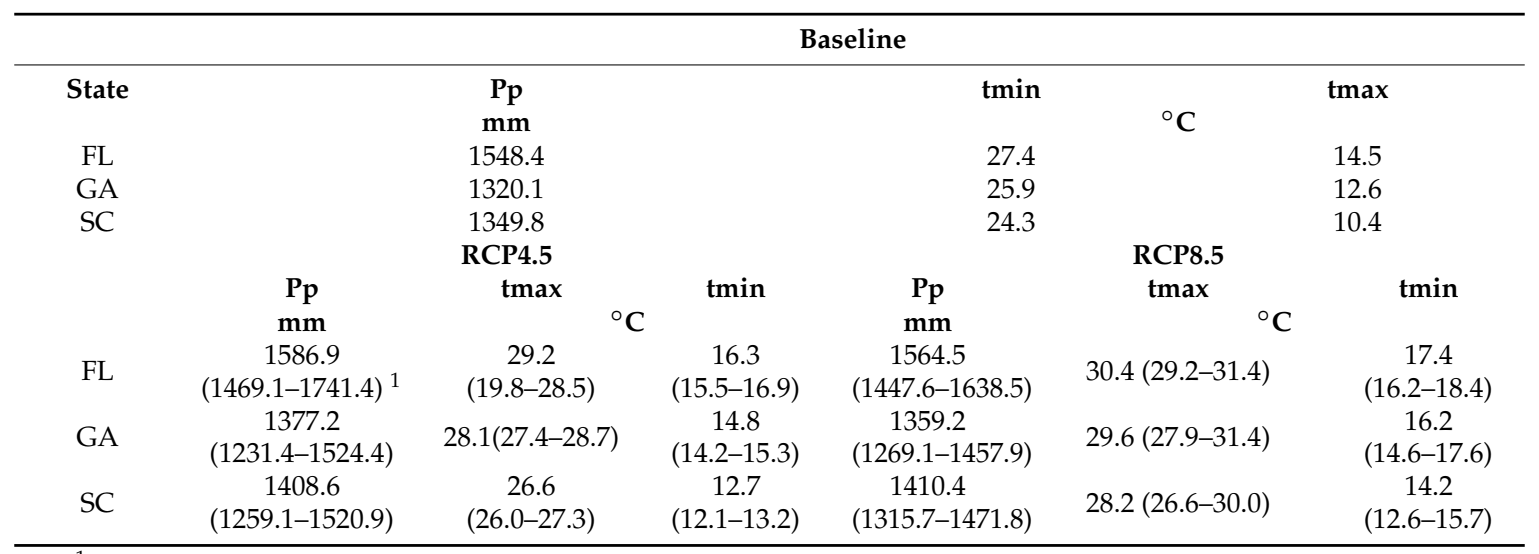

${ }^{1}$ Values between parentheses represent minimum and maximum values for each variable. FL, Florida; GA, Georgia; $\mathrm{SC}$, South Carolina; $\mathrm{RCP}$, representative concentration pathway. 


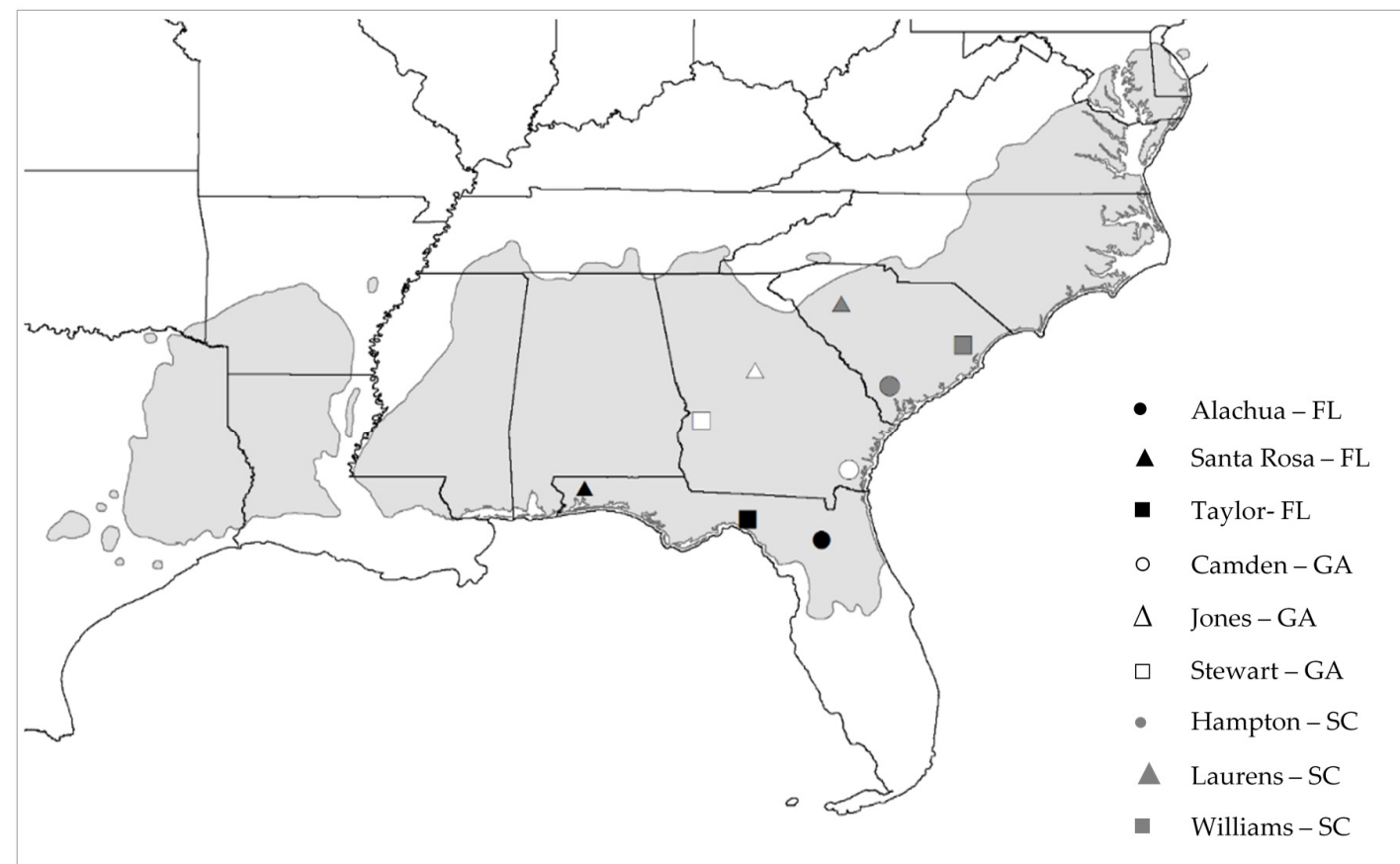

Figure 1. Location of the sites in the southeastern United States (SE US). FL, Florida; GA, Georgia; SC, South Carolina.

\subsection{Forest Management and Economic Parameters}

For each site, we considered two levels of productivity: site index $(\mathrm{SI})=20$ and $28 \mathrm{~m}$; and two initial planting densities: $\mathrm{PD}=750$ trees and 2250 trees ha ${ }^{-1}$. We scheduled two thinnings at ages 12 and 18 years, each one with a tree removal intensity rate of $33 \%$. The different SIs and PDs, ages and intensity of thinnings are consistent with ranges reported for southern pines in SE US [40]. The total simulation permutations of climate, forest regimes (thinned and unthinned), and silvicultural management was 24 for each site ( 3 climates $\times 2$ forest management regimes $\times 2 \mathrm{SI} \times 2 \mathrm{PD}$ ).

Depending on the location of each site, we employed the real average FL, GA, and SC stumpage prices) for sw, cns, and pw between the period 2010 and 2015 [41-46] - base year 2015, nominal prices deflated using the producer price index logging industry [47]. The regeneration (site preparation, weed control, planting and seedling operations) and silvicultural (fertilization and weed control) costs were procured from Barlow and Levendis [48]. We conservatively assumed that the price of water was equal to the cost of pumping groundwater from the upper Floridan aquifer [49], which is a major sources of ground water underlying an area of around 26 million ha including Alabama (AL), FL, GA, Mississippi (MS), and SC, and provides drinking water for about 10 million people in SE US [50]. We further assume a real discount rate of 0.04 , which is between the $3 \%-5 \%$ range of values commonly used for forest economic analysis in the SE US [51]. See Table 2 for a summary of the economic parameters used in our analysis.

Table 2. Economic parameters for loblolly pine.

\begin{tabular}{cccc}
\hline Stumpage Prices & Sawtimber $\boldsymbol{P}_{\boldsymbol{s w}}$ & Chip and saw $\boldsymbol{P}_{\boldsymbol{c n s}}$ & Pulpwood $\boldsymbol{P}_{\boldsymbol{p} w}$ \\
\hline & & $\$ \mathrm{~m}^{-3}$ & \\
\hline FL & 32.8 & 19.8 & 11.8 \\
\hline GA & 31.9 & 19.7 & 12.4 \\
\hline SC & 30.9 & 20.5 & 11.9 \\
\hline Price of water & Water price Pw $\$ \mathrm{~kL}^{-1} 0.1$ & \multicolumn{2}{c}{ Discount rate $r$ 0.04 } \\
\hline
\end{tabular}


Table 2. Cont.

\begin{tabular}{|c|c|c|c|}
\hline Stumpage Prices & Sawtimber $P_{s w}$ & Chip and saw $P_{c n s}$ & Pulpwood $P_{p w}$ \\
\hline \multirow{3}{*}{ Regeneration costs } & Site preparation & Weed control & Planting/Seedling \\
\hline & \multicolumn{2}{|c|}{$\$ \mathrm{ha}^{-1}$} & $\$$ seedling $^{-1}$ \\
\hline & 237 & 108 & $0.08 / 0.05$ \\
\hline \multirow{3}{*}{ Silvicultural costs } & \multicolumn{2}{|c|}{ Fertilization (year 3) } & Weed control (year 1) \\
\hline & \multicolumn{3}{|c|}{$\$$ ha $^{-1}$} \\
\hline & \multicolumn{2}{|c|}{198} & 33 \\
\hline
\end{tabular}

\subsection{Model Application}

To determine the impacts of payments for increased water yield on optimal loblolly pine forest management, we first investigated the feasibility of certain forest management scenarios to increase the water yield under climate change. The feasibility of forest management scenarios was investigated under the following climate change and forest management conditions:

(i) only changes in climatic conditions can increase water yield, isolating the impact of thinnings (CC). For each site and same SI and PD, we compared the water yield generated by thinned loblolly pine forests under current climatic conditions (baseline) and the water yield generated by thinned loblolly pine forests under changing climatic conditions (Scenarios RCP4.5 and RCP8.5);

(ii) both climate change and thinnings can increase water yield (CCT). For each site, and same SI and PD, we compared the water yield generated by unthinned loblolly pine forests under current climatic conditions (baseline) vs. the water yield generated by thinned loblolly pine forests under climate change (scenario RCP4.5 and RCP8.5); and

(iii) climate change, thinnings, and changes in PD can increase water yield (CCTPD). For each site and SI, we compared the water yield generated by unthinned loblolly pine forests with a high PD (2250 trees ha ${ }^{-1}$ ) under current climatic conditions (baseline) vs. the water yield generated by thinned loblolly pine forests with a low PD (750 trees ha $\left.{ }^{-1}\right)$ under climate change (Scenarios RCP4.5 and RCP8.5).

For (i)-(ii) we discarded as inferior those scenarios in which the average difference in water yield was negative $\left(\Delta W=W^{c c}-W^{n c}<0\right)$. Those scenarios that increased water yield were selected to determine the monetary of values on increased water yield and their impacts on their LEVs and the optimal harvest age (Equations (1) and (2)). Furthermore, for all these three original hypotheses, and similarly to Susaeta et al. [25], we assumed that monetary incentives are paid only if landowners decide to modify their forest management practices to generate increases in water yield versus baseline conditions. Assigning monetary payments for water yield without considering changes in forest management or environmental conditions (i.e., no baseline) would overestimate the impacts of forest management on water production.

\section{Results}

\subsection{Water Yield and Feasibility of Forest Management Scenarios}

Table 3 reports the 50-year average fluctuations in water yield between baselines and climatic scenarios for each site and the feasible forest management scenarios that increase water yield. 
Table 3. Average fluctuations in water yield for each site and forest management for the climatic scenarios.

\begin{tabular}{|c|c|c|c|c|c|c|c|c|}
\hline Sites & SI & PD & RCP4.5 & RCP8.5 & RCP4.5 & RCP8.5 & RCP4.5 & RCP8.5 \\
\hline & & & \multicolumn{2}{|c|}{ (i) $\mathrm{CC}$} & \multicolumn{2}{|c|}{ (ii) $\mathrm{CCT}$} & \multicolumn{2}{|c|}{ (iii) CCTPD } \\
\hline & $\mathrm{m}$ & trees ha ${ }^{-1}$ & & & & kL & & \\
\hline \multirow[b]{2}{*}{ Alachua } & 20 & $\begin{array}{c}750 \\
2250\end{array}$ & $\begin{array}{l}-713.5 \\
-769.7\end{array}$ & $\begin{array}{l}-1466.0 \\
-1026.7\end{array}$ & $\begin{array}{l}-267.5 \\
-326.4\end{array}$ & $\begin{array}{l}-1000.0 \\
-1064.4\end{array}$ & $\begin{array}{c}866.1^{2} \\
\text { n.a. }{ }^{3}\end{array}$ & $\begin{array}{c}133.6 \\
\text { n.a. }\end{array}$ \\
\hline & 28 & $\begin{array}{c}750 \\
2250\end{array}$ & $\begin{array}{l}-438.6 \\
-302.5\end{array}$ & $\begin{array}{c}-118.9 \\
-1006.0\end{array}$ & $\begin{array}{l}-310.5 \\
-242.5\end{array}$ & $\begin{array}{c}-1054.9 \\
-946.0\end{array}$ & $\begin{array}{c}342.3 \\
\text { n.a. }\end{array}$ & $\begin{array}{c}-402.1 \\
\text { n.a. }\end{array}$ \\
\hline \multirow[b]{2}{*}{ Santa Rosa } & 20 & $\begin{array}{c}750 \\
2250\end{array}$ & $\begin{array}{l}-1374.4 \\
-1439.7\end{array}$ & $\begin{array}{c}-1405.6 \\
-59.4\end{array}$ & $\begin{array}{l}-904.9 \\
-955.6\end{array}$ & $\begin{array}{c}-936.2 \\
-1015.0\end{array}$ & $\begin{array}{c}254.1 \\
\text { n.a. }\end{array}$ & $\begin{array}{l}222.8 \\
\text { n.a. }\end{array}$ \\
\hline & 28 & $\begin{array}{c}750 \\
2250\end{array}$ & $\begin{array}{c}-1131.8 \\
-951.9\end{array}$ & $\begin{array}{c}-1161.0 \\
-964.8 \\
\end{array}$ & $\begin{array}{l}-965.4 \\
-863.3 \\
\end{array}$ & $\begin{array}{l}-994.6 \\
-876.2 \\
\end{array}$ & $\begin{array}{c}-219.1 \\
\text { n.a. }\end{array}$ & $\begin{array}{c}-248.3 \\
\text { n.a. }\end{array}$ \\
\hline \multirow{2}{*}{ Taylor } & 20 & $\begin{array}{c}750 \\
2250\end{array}$ & $\begin{array}{l}-718.8 \\
-748.8\end{array}$ & $\begin{array}{c}-1380.3 \\
-687.2\end{array}$ & $\begin{array}{l}-242.5 \\
-292.9\end{array}$ & $\begin{array}{l}-903.9 \\
-980.1\end{array}$ & $\begin{array}{c}933.0 \\
\text { n.a. }\end{array}$ & $\begin{array}{c}271.6 \\
\text { n.a. }\end{array}$ \\
\hline & 28 & $\begin{array}{c}750 \\
2250\end{array}$ & $\begin{array}{l}-534.2 \\
-371.7\end{array}$ & $\begin{array}{l}-1239.7 \\
-1063.8\end{array}$ & $\begin{array}{l}-366.2 \\
-281.6\end{array}$ & $\begin{array}{c}-1071.7 \\
-973.8\end{array}$ & $\begin{array}{l}377.1 \\
\text { n.a. }\end{array}$ & $\begin{array}{c}-328.4 \\
\text { n.a. }\end{array}$ \\
\hline \multirow[b]{2}{*}{ Camden } & 20 & $\begin{array}{c}750 \\
2250\end{array}$ & $\begin{array}{l}-801.1 \\
-865.8 \\
\end{array}$ & $\begin{array}{c}-1455.8 \\
-666.3\end{array}$ & $\begin{array}{l}-368.9 \\
-426.8 \\
\end{array}$ & $\begin{array}{l}-1023.5 \\
-1093.1 \\
\end{array}$ & $\begin{array}{c}719.2 \\
\text { n.a. }\end{array}$ & $\begin{array}{l}64.6 \\
\text { n.a. }\end{array}$ \\
\hline & 28 & $\begin{array}{c}750 \\
2250\end{array}$ & $\begin{array}{l}-488.1 \\
-325.3\end{array}$ & $\begin{array}{c}-1129.0 \\
-946.2\end{array}$ & $\begin{array}{l}-355.9 \\
-259.5\end{array}$ & $\begin{array}{l}-996.7 \\
-880.5\end{array}$ & $\begin{array}{c}297.1 \\
\text { n.a }\end{array}$ & $\begin{array}{c}-343.8 \\
\text { n.a }\end{array}$ \\
\hline \multirow{2}{*}{ Jones } & 20 & $\begin{array}{c}750 \\
2250\end{array}$ & $\begin{array}{l}-1049.9 \\
-1148.7 \\
\end{array}$ & $\begin{array}{c}-1509.8 \\
-494.0\end{array}$ & $\begin{array}{l}-590.0 \\
-635.9\end{array}$ & $\begin{array}{l}-1049.8 \\
-1129.9 \\
\end{array}$ & $\begin{array}{c}511.1 \\
\text { n.a. }\end{array}$ & $\begin{array}{l}51.3 \\
\text { n.a. }\end{array}$ \\
\hline & 28 & $\begin{array}{c}750 \\
2250\end{array}$ & $\begin{array}{l}-972.5 \\
-734.7\end{array}$ & $\begin{array}{l}-1459.3 \\
-1181.5\end{array}$ & $\begin{array}{l}-727.3 \\
-579.5\end{array}$ & $\begin{array}{l}-1214.1 \\
-1026.3\end{array}$ & $\begin{array}{c}120.3 \\
\text { n.a. }\end{array}$ & $\begin{array}{c}-366.5 \\
\text { n.a. }\end{array}$ \\
\hline \multirow{3}{*}{ Stewart } & 20 & 750 & -987.4 & -1494.0 & -524.2 & -1030.7 & 601.1 & 94.5 \\
\hline & & 2250 & -1057.7 & -539.2 & -566.5 & -1105.7 & n.a. & n.a. \\
\hline & 28 & $\begin{array}{c}750 \\
2250\end{array}$ & $\begin{array}{l}-812.9 \\
-618.4\end{array}$ & $\begin{array}{c}1364.5 \\
-1142.7\end{array}$ & $\begin{array}{l}-613.7 \\
-502.6\end{array}$ & $\begin{array}{l}-1165.2 \\
-1026.8\end{array}$ & $\begin{array}{c}162.0 \\
\text { n.a. }\end{array}$ & $\begin{array}{c}-389.5 \\
\text { n.a. }\end{array}$ \\
\hline \multirow{2}{*}{ Hampton } & 20 & $\begin{array}{c}750 \\
2250 \\
\end{array}$ & $\begin{array}{l}-823.2 \\
-894.6 \\
\end{array}$ & $\begin{array}{c}-1261.7 \\
-469.4 \\
\end{array}$ & $\begin{array}{l}-352.2 \\
-384.1 \\
\end{array}$ & $\begin{array}{l}-790.7 \\
-853.5 \\
\end{array}$ & $\begin{array}{c}785.7 \\
\text { n.a. }\end{array}$ & $\begin{array}{c}347.1 \\
\text { n.a. }\end{array}$ \\
\hline & 28 & $\begin{array}{c}750 \\
2250\end{array}$ & $\begin{array}{l}-708.5 \\
-494.8\end{array}$ & $\begin{array}{c}-1166.7 \\
-919.6\end{array}$ & $\begin{array}{l}-479.9 \\
-358.7\end{array}$ & $\begin{array}{l}-938.1 \\
-783.5\end{array}$ & $\begin{array}{c}347.2 \\
\text { n.a. }\end{array}$ & $\begin{array}{c}-111.1 \\
\text { n.a. }\end{array}$ \\
\hline \multirow[b]{2}{*}{ Lauren } & 20 & $\begin{array}{c}750 \\
2250\end{array}$ & $\begin{array}{l}-1066.9 \\
-1199.0 \\
\end{array}$ & $\begin{array}{c}-1466.7 \\
-433.5\end{array}$ & $\begin{array}{l}-626.6 \\
-659.1 \\
\end{array}$ & $\begin{array}{l}-1026.4 \\
-1092.6\end{array}$ & $\begin{array}{l}466.6 \\
\text { n.a. }\end{array}$ & $\begin{array}{l}66.8 \\
\text { n.a. }\end{array}$ \\
\hline & 28 & $\begin{array}{c}750 \\
2250\end{array}$ & $\begin{array}{c}-1208.1 \\
-937.2\end{array}$ & $\begin{array}{l}-1631.4 \\
-1309.8\end{array}$ & $\begin{array}{l}-891.8 \\
-707.4\end{array}$ & $\begin{array}{l}-1315.1 \\
-1080.1\end{array}$ & $\begin{array}{l}76.1 \\
\text { n.a. }\end{array}$ & $\begin{array}{c}-347.1 \\
\text { n.a. }\end{array}$ \\
\hline \multirow{2}{*}{ Williams } & 20 & $\begin{array}{c}750 \\
2250\end{array}$ & $\begin{array}{l}-1349.6 \\
-1540.3\end{array}$ & $\begin{array}{c}-1857.6 \\
-508.7\end{array}$ & $\begin{array}{l}-962.3 \\
-984.4\end{array}$ & $\begin{array}{l}-1425.3 \\
-1493.1\end{array}$ & $\begin{array}{l}126.8 \\
\text { n.a. }\end{array}$ & $\begin{array}{c}-336.2 \\
\text { n.a. }\end{array}$ \\
\hline & 28 & $\begin{array}{c}750 \\
2250\end{array}$ & $\begin{array}{l}-1713.7 \\
-1519.2\end{array}$ & $\begin{array}{l}-2253.2 \\
-2024.0\end{array}$ & $\begin{array}{l}-1358.4 \\
-1212.5\end{array}$ & $\begin{array}{l}-1897.9 \\
-1717.4\end{array}$ & $\begin{array}{c}-624.2 \\
\text { n.a. }\end{array}$ & $\begin{array}{c}-837.3 \\
\text { n.a. }\end{array}$ \\
\hline
\end{tabular}

\footnotetext{
${ }^{1}$ It represents average variation in water yield. ${ }^{2}$ Numbers in bold reflect the feasible combinations of SI and PD that increase water yield. SI, site index; PD, planting density; CC, only changes in climatic conditions can increase water yield; CCT, both climate change and thinnings can increase water yield; CCTPD, climate change, thinnings, and changes in PD can increase water yield. ${ }^{3}$ Non applicable.
}

Moderate and extreme variations in climatic conditions (CC, Scenarios RCP4.5 and RCP8.5, respectively) decreased water yield in thinned loblolly pine forests in all sites for all combinations of SI and PD. On average, the total losses of water for all sites were 911 and $1042 \mathrm{~kL} \cdot \mathrm{ha}^{-1}$, respectively, with the greatest losses occurring in SC. Likewise, when also considering the impact of thinnings (CCT), water yield decreased for all sites, averaging losses of 587 and $1082 \mathrm{~kL} \cdot \mathrm{ha}^{-1}$, respectively, for Scenarios RCP4.5 and RCP8.5.

However, when also considering changes in initial planting density of loblolly pines at all sites (CCTPD), several sites saw increases in water yield. On average, water yield increased by $7.6 \%$ and 
$2.9 \%$ for SI $=20 \mathrm{~m}$ and $28 \mathrm{~m}$ (RCP4.5), respectively, and 1.3\% for SI = $20 \mathrm{~m}$ (RCP8.5) (Table S1). Water yield increased by an average of $341 \mathrm{~kL} \cdot \mathrm{ha}^{-1}$ under Scenario RCP4.5 for all combinations of SI and PD $=750$ trees ha ${ }^{-1}-584 \mathrm{~kL} \cdot \mathrm{ha}^{-1}$ when $\mathrm{SI}=20 \mathrm{~m}$, and $97 \mathrm{~kL} \cdot \mathrm{ha}^{-1}$ when $\mathrm{SI}=28 \mathrm{~m}$. Under Scenario RCP8.5, water yield was increased by an average of $100 \mathrm{~kL} \cdot \mathrm{ha}^{-1}$ with SI $=20 \mathrm{~m}$ and $\mathrm{PD}=750$ trees $\mathrm{ha}^{-1}$, with water yield falling only at one site (Williams, SC, USA). Overall, when considering water yield impacts within each state (three sites considered together), changes in PD and thinnings under extreme climatic conditions (RCP8.5) tended to decrease water yield, resulting in negative savings of water after rotation age of 22 years (Figure S1).

\subsection{Land Expectation Values LEVs and Feasible Forest Management Scenarios}

Using the economic model presented in Section 2, we determined the optimal harvest age that maximizes the LEV (timber and water yield revenues) for those climatic and forest management scenarios that increased water yield. Moderate changes in climate (scenario RCP4.5) with a low PD and SI increased the LEVs for thinned loblolly pine forests in all sites compared to LEVs generated by unthinned loblolly pine forests with 2250 trees ha ${ }^{-1}$ under current climatic conditions (Table 4). Greater land values were obtained in sites in FL compared to those in GA and SC-on average $14 \%$ and $82 \%$ greater LEVs, respectively-yet increased economic returns were accentuated in northern distribution of loblolly pine-the LEVs in SC, GA, and FL increased by $101 \%, 102 \%$, and $83 \%$, respectively, compared to the baseline. On average, the harvest ages were extended for all sites in FL and only Stewart in GA, 2 years and 1 year, respectively, longer than managing loblolly pine only for the production of timber.

Table 4. Land expectation value (LEV), monetary value of increased water yield $(\mathrm{H})$, and optimal harvest age $\left(\mathrm{T}^{*}\right)$ in all loblolly pine sites with $\mathrm{SI}=20 \mathrm{~m}$ and $28 \mathrm{~m}$ and $\mathrm{PD}=750$ trees $\mathrm{ha}^{-1}$ for all climatic scenarios.

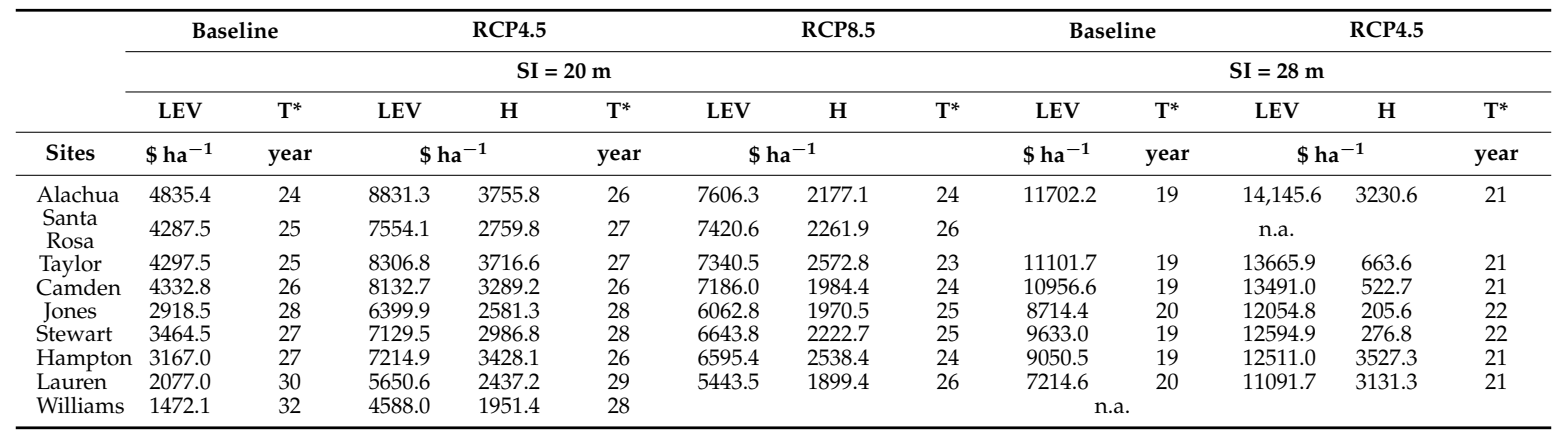

The economic returns generated by payments for increased water yield had the greatest impact on the sites in FL (average of $\$ 3408.0 \mathrm{ha}^{-1}$ ) followed by the sites in GA ( $\$ 2946.8 \mathrm{ha}^{-1}$ ) and SC $\left(\$ 2591.8 \mathrm{ha}^{-1}\right.$ ) (Table 4). Overall, the increase in the land values were driven more by the impacts of climate and planting density on forest growth than the payments for increased water yield. However, the contribution of payments for increased water yield $(\mathrm{H})$ to the total LEV was still significant-on average, $41 \%, 41 \%$, and $44 \%$ for the sites in FL, GA, and SC.

Extreme climatic conditions (scenario RCP8.5) and payments for water yield accentuated the gains in economic returns with respect to land values generated under current climatic conditions only in SC (Table 4). LEVs increased by $131 \%, 85 \%$, and $67 \%$, respectively, in SC, GA, and FL sites. These extreme environmental conditions and the payments for increased water yield only extended the harvest age in Santa Rosa in FL. On average, all sites in GA and SC reduced their harvest ages by 2.3 and 3.2 years. The contribution of payments for increased water yield to the total land values decreased compared to moderate changes in climate-now accounting for $31 \%$ of the LEVs for sites in FL and GA, and $16 \%$ of the LEV for sites in SC.

Climatic variables such as minimum and maximum temperatures were a significant driver of the increased LEVs in all the states ( $p<0.001$; Figure $2 b, c$ and Figure $S 2 b, c)$. For an average increase of the 
maximum and minimum temperatures of 1.76 and $1.79{ }^{\circ} \mathrm{C}$, stands with $\mathrm{SI}=20$ and $28 \mathrm{~m}$ averaged LEVs of $\$ 6073.9 \mathrm{ha}^{-1}$ and $\$ 10,326.0 \mathrm{ha}^{-1}$, respectively, for Scenario RCP4.5 in FL. In the case of Scenario RCP8.5, for an average increase of the maximum and minimum temperatures of 2.94 and 2.97, LEVs averaged $\$ 5158.5 \mathrm{ha}^{-1}$ and $\$ 9680.9 \mathrm{ha}^{-1}$, respectively. Unexpectedly, the impact of precipitation on future LEVs was not statistically significant ( $p>0.1$; Figure 2a; Figure S2a).
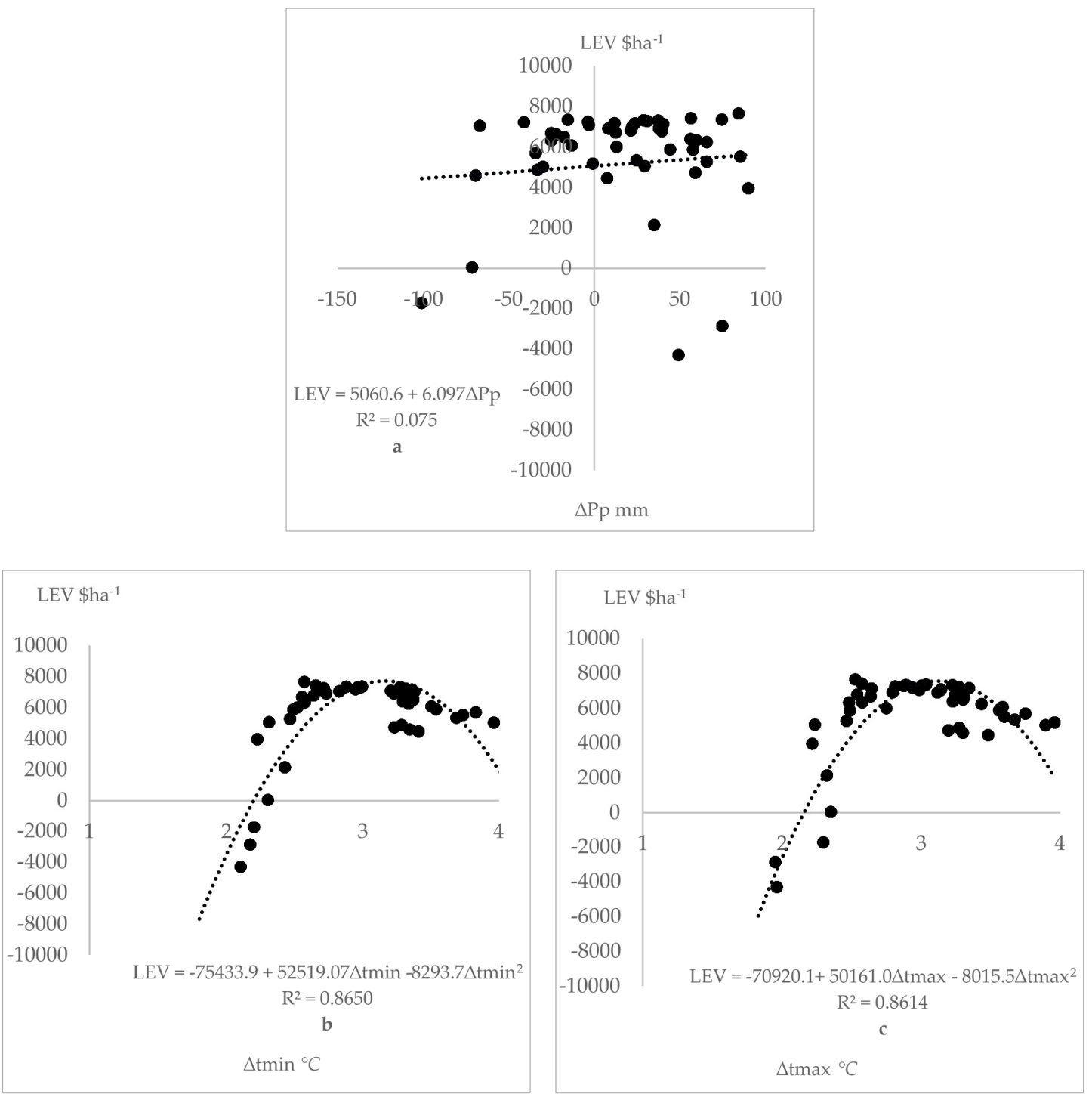

Figure 2. Relationship between land expectation values (LEVs) and variations in precipitation $\Delta \mathrm{Pp}(\mathbf{a})$; minimum temperatures $\Delta \operatorname{tmin}(\mathbf{b})$; and maximum temperatures $\Delta \operatorname{tmax}$ (c) in loblolly pine stands with SI $=20 \mathrm{~m}$ and PD $=750$ trees ha ${ }^{-1}$ for climatic Scenario RCP8.5 in FL. A linear curve was fitted to (a) and a quadratic curve was fitted to (b) and (c).

When planting loblolly pine under higher productivity conditions $(\mathrm{SI}=28 \mathrm{~m})$, moderate climatic conditions would also increase the economic returns for forest landowners in FL, GA, and SC sites (Table 4). In these states, the land values increased by $22 \%, 34 \%$, and $29 \%$, respectively, compared to those obtained under current climatic conditions. Compared to planting loblolly pine trees under lower productivity conditions $(\mathrm{SI}=20 \mathrm{~m}$ ), the contribution of water yield payments to the total LEVs was approximately $4 \%, 2 \%$, and $3 \%$, respectively, for sites in FL, GA, and SC. Similar to the case of $\mathrm{SI}=20 \mathrm{~m}$, the harvest ages were increased for all sites compared to current climatic conditions, averaging 24 years. 


\section{Discussion}

Our results suggest that water yield would increase when planting fewer trees either under low site productivity conditions with moderate or extreme changing climatic conditions, or under high productivity conditions with moderate changing climatic conditions. On average, one hectare of low productivity loblolly pine could increase water yield by $13.7,12.2$, and $9.2 \mathrm{~kL} \cdot \mathrm{yr}^{-1}$, respectively, under moderate climatic conditions in FL, GA, and SC (Table S2). This represents an $8.3 \%, 9.0 \%$, and $5.6 \%$ increase in water yield, respectively. Also, planting loblolly pine trees under high productivity conditions with moderate climatic conditions would results in lower savings of water. On average, one hectare of loblolly pine would increase water yield by $7.2(3.1 \%), 2.8(4.8 \%)$, and $4.2(1 \%) \mathrm{kL} \cdot \mathrm{yr}^{-1}$ (Table S2). Our findings on increases in water yield are in line with those obtained by Sun et al. [21] who reported an increase of water yield in loblolly pine between 3\%-13\% using other climate models. Our water yield estimates are far below of the values suggested by McLaughlin et al. [23] (64\%) and Edwards et al. [52] (23\%), who did not include the combined effects of climate and forest management.

Managing loblolly pine forests for water conservation under changing climatic conditions is timely, since it could help offset public and domestic water consumption. However, the increase in water savings is modest. In 2010, groundwater withdrawals in FL, GA, and SC for public supply and self-supplied domestic water consumption were roughly 2787, 337, and $158 \mathrm{bL}$, and, 296, 159, and $159 \mathrm{bL}$, respectively [53]. Private loblolly pine forests in FL, GA, and SC cover around 0.5, 2.8, and 2 million ha, respectively [54]. If $20 \%$ of the private forests in these states were managed for water production under low productivity conditions and moderate climatic conditions, they could increase effective water yield by around $<1 \%, 2 \%$, and $2 \%$ of the annual public supply water consumption in FL, GA, and SC. In the case of groundwater withdrawals for self-supplied domestic water consumption, yearly increased water savings yield could reach $<1 \%, 4 \%$, and $2 \%$, respectively.

Under high productivity conditions, loblolly pine forests could increase water yield by $<1 \%$ of the public supply of water consumption in FL and GA, and 1\% of the same groundwater withdrawal in SC. In the case of self-supplied domestic water consumption, the increase in water savings would reach $<1 \%, 1 \%$, and $1 \%$, respectively. Furthermore, changes in forest management such as thinnings and the reduction of tree planting density to increase water productions are also timely considering that around $60 \%$ of the loblolly pine forests are near or beyond their optimal harvest date [54]. Our findings demonstrated the critical role that forests play in the sustainable provision of timber; while also illustrating their potential contribution to water availability. Given that water resources are likely to become a pressing issue given forest losses due to expanding urbanization, population increases, and higher temperatures expected in the region $[4,9,55]$, it is necessary to consider other coupled alternatives to increase water savings such as improving efforts for soil conservation, developing high efficiency water irrigation systems, and introducing economically attractive conservation easements for water management.

Our results indicated that for most of the cases in this study, the collective impacts of climate change, modifications of forest management, and payments for increased water yield would increase the economic rents for landowners. Although a sensitivity analysis of different parameters of our model were not included in our study, it is rather intuitive that, for example, the LEV will increase with higher prices for increased water yield [25], or decrease with lower timber prices and higher discount rates $[32,56]$. Our results indicated that the average economic benefits of managing loblolly pine for water production $(\mathrm{H})$ for all sites ranged between $\$ 1894.8 \mathrm{ha}^{-1}$ (Scenario RCP8.5) and $\$ 2530.7 \mathrm{ha}^{-1}$ (Scenario RCP4.5). Incorporating climatic variables resulted in greater economic estimates compared to other studies such as Susaeta et al. [25] who found that the economic benefits of managing forests for water production could be up to $\$ 940 \mathrm{ha}^{-1}$.

Harvest ages for loblolly pine stands might also be extended, depending on the type of climatic scenario and the site location. Longer rotation ages are in general obtained when age increasing non-timber benefits are considered [32]. However, other studies such as Susaeta et al. [25] have suggested that, absent climate considerations, payments for water yield increases do not have an 
impact on the harvest age for loblolly pine. Despite the positive economic effects of extending the harvest age, other studies have also suggested that, from a water conservation perspective, older forests have greater evapotranspiration given their larger leaf area index which intercept more water-leading to decreases in water availability [9]. However, the type of forests and management goal could also offset the positive effects of reduced harvest ages on water yield. For example, fast growing species for bioenergy production or carbon sequestration, or the use of pine plantations that consume more water than unmanaged pines can have negative consequences for water yield and water quality $[9,57]$.

There are several avenues for further research on the role of forests water yield. First, the use of several climatic models (see, for example, the Coupled Model Intercomparison Project CMPI5 models; [58]) may give a wider spectrum of future precipitation and temperatures to more accurately estimate forest growth simulations and water yield. Second, we conducted our economic analysis using a value of $\$ 0.1 \mathrm{~kL}^{-1}$ for increased water yield, which reflected, a contribution of the economic benefits of managing the forests for water production of 38\% and 30\%, respectively, of the land expectation values for climatic scenarios RCP4.5 and RCP8.5. As we expect stronger markets for forest based water conservation in the future-coupled with higher rates of forest growth due to changing climatic conditions [6-8] - it is likely that the price of water will also increase, generating more economic returns for forest landowners and thereby ensuring the sustainability of southern forestlands. The tradeoffs between ecosystem services $[59,60]$ (e.g., planting more trees may increase carbon sequestration but also increase water used by trees) and the role of disturbance [61,62] are also subjects of further research in this context.

\section{Conclusions}

Our study analyzed the impact of climate change, thinning schedules, and different forest productivity conditions regimes on the water yield and land expectation values of loblolly pine stands in the SE US. Our findings suggested that climate change and thinnings would not increase water yield in loblolly pine forests. However, water yield would increase if in addition to thinnings, tree planting density were reduced for both climate scenarios. On average, under climatic scenario RCP4.5, water yield increased by $341 \mathrm{~kL} \cdot \mathrm{ha}^{-1}$ for all sites and productivity conditions-584 $\mathrm{kL} \cdot \mathrm{ha}^{-1}$ when SI $=20 \mathrm{~m}$, and $97 \mathrm{~kL} \cdot \mathrm{ha}^{-1}$ when SI = $28 \mathrm{~m}$. For climatic scenario RCP8.5, water yield only increased by $100 \mathrm{~kL} \cdot \mathrm{ha}^{-1}$ for $\mathrm{SI}=20 \mathrm{~m}$. For an economic perspective, and assuming a payment for increased water yield of $\$ 0.1 \mathrm{~kL}^{-1}, 96 \%$ and $95 \%$ greater land expectation values were obtained under scenarios RCP4.5 (\$6653.7 $\mathrm{ha}^{-1}$ ) and RCP8.5 (\$6424.1 ha $\left.{ }^{-1}\right)$, respectively, compared to those obtained for unthinned loblolly pine forests under low productivity conditions and current climatic conditions. For both climatic scenarios the contributions of payments for increased water yield were $38 \%$ (\$2530.1 $\mathrm{ha}^{-1}$ ) and 30\% (\$1894.8 $\left.\mathrm{ha}^{-1}\right)$, respectively. We also found that the optimal harvest decision did not show a clear trend with the inclusion of payments for increased water yield, and future temperatures were a significant driver of the economic returns, but precipitation was not. Our results suggest that managing loblolly pine forests for timber and water conservation would economically benefit forest landowners, but joint efforts are required to improve the sustainability of forestlands in terms of the provision of ecosystem services in the SE US.

Supplementary Materials: The following are available online at www.mdpi.com/1999-4907/8/3/83/s1, Figure S1: Variation in water yield $(\Delta W)$ in thinned loblolly pine stands with $P D=750$ trees ha ${ }^{-1}$ and $\mathrm{SI}=20 \mathrm{~m}$ for different climatic scenarios in FL, GA, and SC, Figure S2: Relationship between land expectation values (LEVs) and variations in precipitation $\Delta \mathrm{Pp}(\mathrm{a})$; maximum temperatures $\Delta$ tmax (b); and minimum temperatures $\Delta \operatorname{tmin}(c)$ in loblolly pine stands with $\mathrm{SI}=20 \mathrm{~m}$ and $\mathrm{PD}=750$ trees $\mathrm{ha}^{-1}$ for climatic Scenario RCP8.5 in GA, and SC. A linear curve was fitted to (a) and a quadratic curve was fitted to (b) and (c). Table S1: State average water yield $(\bar{W})$ and increased water yield $(\overline{\Delta W})$ under different climatic scenarios, Table S2: Annual average increase in water yield $\left(\overline{\Delta W_{a}}\right)$ for all sites and climatic scenarios. 
Acknowledgments: This work was supported by The Pine Integrated Network: Education, Mitigation, and Adaptation project (PINEMAP); a Coordinated Agricultural Project funded by the USDA National Institute of Food and Agriculture, Award \#2011-68002-30185. We also want to thank the University of Florida Water Institute for their valuable comments on this paper.

Author Contributions: The paper was written by Andres Susaeta with significant contribution by Damian C. Adams. Andres Susaeta identified the research questions and designed the study with contributions from Damian C. Adams and Jose R. Soto. Carlos Gonzalez-Benecke performed the forest growth simulation. Andres Susaeta performed the economic analyses with guidance from co-authors.

Conflicts of Interest: The authors declare no conflict of interest.

\section{Abbreviations}

The following abbreviations are used in this manuscript:

$\begin{array}{ll}\text { LEV } & \text { land expectation value } \\ \text { PD } & \text { planting density } \\ \text { FL } & \text { Florida } \\ \text { GA } & \text { Georgia } \\ \text { SC } & \text { South Carolina }\end{array}$

\section{References}

1. Environmental Protection Agency (EPA). Climate Change Indicators in the United States, 4th ed.; EPA Environmental Protection Agency Report 430-R-16-004; Environmental Protection Agency: Washington, DC, USA, 2016; p. 92.

2. Intergovermental Panel on Climate Change (IPCC). Summary for Policymakers. In Climate Change 2013: The Physical Science Basis. Working Group I Contribution to the Fifth Assessment Report of the Intergovermental Panel on Climate Change; Stocker, T., Qin, D., Plattner, G.-K., Tignor, M., Allen, S., Boschung, J., Eds.; Intergovernmenal Panel on Climate Change: Cambridge, NY, USA, 2013; p. 1535.

3. Mcnulty, S.; Caldwell, P.; Doyle, T.; Johnsen, K.; Liu, Y.; Mohan, J.; Prestemon, J.; Sun, G. Forests and Climate Change in the Southeast USA. In Climate of the Southeast United States: Variability, Change, Impacts, and Vulnerability; Ingram, K., Dow, K., Carter, L., Anderson, J., Eds.; Island Press: Washington, DC, USA, 2013; pp. 165-189.

4. Wear, D.N.; Greis, J. The Southern Forest Futures Project: Summary Report; General Technical Report SRS-168; U.S. Department of Agriculture Forest Service, Southern Research Station: Asheville, NC, USA, 2012; p. 54.

5. National Oceanic and Atmospheric Administration (NOAA). Regional Climate Trends and Scenarios for the U.S. National Climate Assessment. Part 2. Climate of the Southeast U.S.; NOAA Technical Report NESDIS 142-2; National Oceanic and Atmospheric Administration: Washington, DC, USA, 2013; p. 94.

6. Wertin, T.M.; McGuire, M.A.; Teskey, R.O. Effects of predicted future and current atmospheric temperature and $\left[\mathrm{CO}_{2}\right]$ and high and low soil moisture on gas exchange and growth of Pinus taeda seedlings at cool and warm sites in the species range. Tree Physiol. 2012, 32, 847-858. [CrossRef] [PubMed]

7. Wang, D.; Heckathorn, S.A.; Wang, X.; Philpott, S.M. A meta-analysis of plant physiological and growth responses to temperature and elevated CO(2). Oecologia 2012, 169, 1-13. [CrossRef] [PubMed]

8. Quinn Thomas, R.; Ahlswede, B. Regional Carbon Cycle Predictions Using Community Land Model; Year 4 Annual PINEMAP Report; Pine Integrated Network: Education, Mitigation and Adaptation Project: Gainesville, FL, USA, 2015.

9. Lockaby, G.; Nagy, C.; Vose, J.; Ford, C.; Sun, G.; Mcnulty, S.G.; Caldwell, P.V.; Cohen, E.; Moore Myers, J. Forests and Water. In The Southern Forest Futures Project: Technical Report; Wear, D.N., Greis, J., Eds.; General Technical Report SRS-178; U.S. Department of Agriculture Forest Service Southern Research Station: Asheville, NC, USA, 2013; pp. 309-339.

10. Sun, G.; Caldwell, P.; Mcnulty, S.; Ward, E.; Domec, J.C.; Noormets, A. Regional Carbon Sequestration and Climate Change: It's All about Water; Year 2 PINEMAP Annual Report; Pine Integrated Network: Education, Mitigation and Adaptation Project: Gainesville, FL, USA, 2013.

11. Peterson, D.L.; Wolken, J.M.; Hollingsworth, T.N.; Giardina, C.P.; Littell, J.S.; Joyce, L.A.; Swanston, C.W.; Handler, S.D.; Rustad, L.E.; Mcnulty, S.G. Regional Highlights of Climate Change. In Climate Change and United States Forests; Peterson, D.L., Vose, J.M., Patel-Weynand, T., Eds.; Springer Science + Business Media: New York, NY, USA, 2014; p. 261. 
12. Stanturf, J.A.; Goodrick, S.L. Fire. In The Southern Forest Futures Project: Technical Report; Wear, D., Greis, J., Eds.; General Technical Report SRS-178; U.S. Department of Agriculture Forest Service Southern Research Station: Asheville, NC, USA, 2013; p. 542.

13. Gonzalez-Benecke, C.A.; Teskey, R.O.; Martin, T.A.; Jokela, E.J.; Fox, T.R.; Kane, M.B.; Noormets, A. Forest Ecology and Management Regional validation and improved parameterization of the 3-PG model for Pinus taeda stands. For. Ecol. Manag. 2016, 361, 237-256. [CrossRef]

14. Oswalt, S.N.; Smith, W.B.; Miles, P.D.; Pugh, S.A. Forest Resources of the United States, 2012: A Technical Document Supporting the Forest Service 2015 Update of the RPA Assessment; General Technical Report GTR-WO-91; U.S. Department of Agriculture Forest Service Washington Office: Washington, DC, USA, 2014.

15. PINEMAP. Pine Integrated Network: Education, Mitigation and Adaptation Project. Available online: http:/ / www.pinemap.org/ (accessed on 1 January 2017).

16. Han, F.X.; Plodinec, M.J.; Su, Y.; Monts, D.L.; Li, Z. Terrestrial carbon pools in southeast and south-central United States. Clim. Chang. 2007, 84, 191-202. [CrossRef]

17. Sun, G.; Caldwell, P.; Mcnulty, S.; Georgakakos, A.; Arumugan, S.; Cruise, J.; Mcnider, R.; Terando, A.; Conrads, P.; Feldt, J.; et al. Impacts of Climate Change and Variability on Water Resources in the Southeast USA; NCA Southeast Technical Report 204-234; U.S. Department of Agriculture Forest Service, Island Press/Center for Resource Economics: Washington, DC, USA, 2013.

18. Dai, Z.; Amatya, D.; Sun, G.; Trettin, C.; Li, C.; Li, H. Climate variability and its impact on forest hydrology on South Carolina Coastal Plain, USA. Atmosphere (Basel) 2011, 2, 330-357. [CrossRef]

19. Milly, P.; Dunne, K.; Vecchia, A. Global pattern of trends in streamflow and water availability in a changing climate. Nature 2005, 438, 347-350. [CrossRef] [PubMed]

20. Sankarasubramanian, A.; Vogel, R.M.; Limbrunner, J.F. Climate elasticity of streamflow in the United States and calibration. Water Resour. Res. 2001, 37, 1771-1781. [CrossRef]

21. Sun, G.; Caldwell, P.V.; Mcnulty, S.G. Modelling the potential role of forest thinning in maintaining water supplies under a changing climate across the conterminous United States. Hydrol. Process. 2015, 5030, 5016-5030. [CrossRef]

22. Grant, G.E.; Tague, C.L.; Allen, C.D. Watering the forest for the trees: An emerging priority for managing water in forest landscapes. Front. Ecol. Environ. 2013, 11, 314-321. [CrossRef]

23. McLaughlin, D.L.; Kaplan, D.A.; Cohen, M.J. Managing forests for increased regional water yield in the southeastern U.S. Coastal Plain. J. Am. Water Resour. Assoc. 2013, 49, 953-965. [CrossRef]

24. Grace, J.M.; Skaggs, R.W.; Chescheir, G.M. Hidrologic and water quality effects of thinning loblolly pine. Trans. Agric. Biol. Eng. 2006, 49, 645-654.

25. Susaeta, A.; Soto, J.R.; Adams, D.C.; Allen, D.L. Economic Sustainability of Payments for Water Yield in Slash Pine Plantations in Florida. Water 2016, 8, 382. [CrossRef]

26. Creedy, J.; Wurzbacher, A.D. The economic value of a forested ctachment with timber, water and carbon sequestration benefits. Ecol. Econ. 2001, 38, 71-83. [CrossRef]

27. Bowes, M.D.; Krutilla, J.V.; Sherman, P.B. Forest management for increased timber and water yields. Water Resour. Res. 1984, 20, 655-663. [CrossRef]

28. Caldwell, P.; Muldoon, C.; Miniat, C.F.; Cohen, E.; Krieger, S.; Sun, G.; Mcnulty, S.; Bolstad, P.V. Quantifying the Role of National Forest System Lands in Providing Surface Drinking Water Supply for the Southern United States; General Technical Report SRS-197; Department of Agriculture Forest Service Southern Research Station: Asheville, NC, USA, 2014; p. 135.

29. Hugget, R.; Wear, D.N.; Li, R.; Coulston, J.; Liu, S. Forecasts of Forest Conditions. In The Southern Forest Futures Project: Technical Report; Wear, D.N., Greis, J., Eds.; U.S. Department of Agriculture Forest Service: Asheville, NC, USA, 2013; pp. 73-101.

30. Schultz, R. Loblolly Pine: The Ecology and Culture of Loblolly Pine (Pinus taeda L.); U.S. Department of Agriculture, Forest Service Handbook 713: Washington, DC, USA, 1997.

31. Landsberg, J.; Waring, R.H. A generalized model of forest productivity using simplified concepts of radiation use efficiency, carbon balance and partitioning. For. Ecol. Manag. 1997, 95, 209-228. [CrossRef]

32. Hartman, R. The harvesting decision when a standing forest has value. Econ. Inq. 1976. [CrossRef]

33. Gonzalez-Benecke, C.A.; Jokela, E.J.; Cropper, W.P.; Bracho, R.; Leduc, D.J. Parameterization of the 3-PG model for Pinus elliottii stands using alternative methods to estimate fertility rating, biomass partitioning and canopy closure. For. Ecol. Manag. 2014, 327, 55-75. [CrossRef] 
34. Coops, N.C.; Hember, R.A.; Waring, R.H. Assessing the impact of current and projected climates on Douglas-Fir productivity in British Columbia, Canada, using a process-based model (3-PG ). Can. J. For. Res. 2010, 524, 511-524. [CrossRef]

35. Pérez-Cruzado, C.; Muñoz-Sáez, F.; Basurco, F.; Riesco, G.; Rodríguez-Soalleiro, R. Combining empirical models and the process-based model 3-PG to predict Eucalyptus nitens plantations growth in Spain. For. Ecol. Manag. 2011, 262, 1067-1077. [CrossRef]

36. Landsberg, J.; Sands, P. Physiological Ecology of Forest Production: Principles, Processes and Models; Academic Press Elsevier: Burlington, MA, USA, 2011; p. 352.

37. Pienaar, L.V.; Shiver, B.D.; Rheney, J.W. Yield Prediction for Mechanically Site-Prepared Slash Pine Plantations in the Southeastern Coastal Plain; PMRC Technical Report 1996-3A; University of Georgia: Athens, GA, USA, 1996.

38. Intergovermental Panel on Climate Change (IPCC). Annex I: Atlas of Global and Regional Climate Projections. In Climate Change 2013: The Physical Science Basis. Working Group I Contribution to the Fifth Assessment Report of the Intergovermental Panel on Climate Change; Stocker, T., Qin, D., Plattner, G.-K., Tignor, M., Allen, S., Boschung, J., Eds.; Cambridge University Press: Cambridge, NY, USA, 2013; p. 1535.

39. University of Idaho Multivariate Adaptive Constructed Analogs (MACA) Statistical Downscaling Method. Available online: http:/ / maca.northwestknowledge.net (accessed on 11 November 2016).

40. Gonzalez-Benecke, C.A.; Martin, T.A.; Cropper, W.P.; Bracho, R. Forest management effects on in situ and ex situ slash pine forest carbon balance. For. Ecol. Manag. 2010, 260, 795-805. [CrossRef]

41. Timber Mart-South. U.S. South Annual Review: 2010 Timber Prices \& Markets; Timber-Mart South: Athens, GA, USA, 2011.

42. Timber Mart-South. U.S. South Annual Review: 2011 Timber Prices E Markets; Timber-Mart South: Athens, GA, USA, 2012.

43. Timber Mart-South. U.S. South Annual Review: 2012 Timber Prices \& Markets; Timber-Mart South: Athens, GA, USA, 2013.

44. Timber Mart-South. U.S. South Annual Review: 2013 Timber Prices \& Markets; Timber-Mart South: Athens, GA, USA, 2014.

45. Timber Mart-South. U.S. South Annual Review: 2014 Timber Prices \& Markets; Timber-Mart South: Athens, GA, USA, 2015.

46. Timber Mart-South. U.S. South Annual Review: 2015 Timber Prices \& Markets; Timber Mart-South: Athens, GA, USA, 2016.

47. USDL Bureau of Labor Statistics. Producer Price Index Industry Data. Available online: https://www.bls. gov/ (accessed on 12 December 2016).

48. Barlow, R.; Levendis, W. 2014 cost and cost trends for forestry practices in the South. For. Landowner 2015, 3, 23-31.

49. Florida Department of Environmental Protection. Report on Expansion of Beneficial Use of Reclaimed Water, Stormwater and Excess Surface Water; Senate Bill 536; Florida Department of Environmental Protection Office of Water Policy: Tallahassee, FL, USA, 2015; p. 230.

50. Berndt, M.P.; KAtz, B.G.; Kingsbury, J.A.; Crandall, C.A. Water Quality in the Upper Floridan Aquifer and Overlying Surficial Aquifers, Southeastern United States, 1993-2010 National Water-Quality Assessment Program Circular 1355; U.S. Geological Survey Circular 1355: Reston, VA, USA, 2014; p. 72.

51. Amacher, G.S.; Malik, A.S.; Haight, R.G. Forest landowner decisions and the value of information under fire risk. Can. J. For. Res. 2005, 35, 2603-2615. [CrossRef]

52. Edwards, P.J.; Troendle, C.A. Water Yield and Hidrology. In Cumulative Watershed Effects of Fule Management in the Eastern United States; Lafayette, R., Brooks, M., Potyond, J., Audin, L., Krieger, S., Trettin, C., Eds.; General Technical Report SRS-161; U.S. Department of Agriculture Forest Service Southern Research Station: Asheville, NC, USA, 2012; pp. 229-281.

53. Maupin, M.A.; Kenny, J.F.; Hutson, S.S.; Lovelace, J.K.; Barber, N.L.; Linsey, K. Estimated Use of Water in the United States in 2010; U.S. Geological Survey Circular 1405: Reston, VA, USA, 2014; p. 56.

54. U.S. Department of Agriculture Forest Service. Forest Inventory Data. Available online: http://apps.fs.fed. us / fia/fido/ (accessed on 11 October 2016).

55. Sun, G.; Mcnulty, S.G.; Myers, J.A.M.; Cohen, E.C. Impacts of multiple stresses on water demand and supply across the Southeastern United States. J. Am. Water Resour. Assoc. 2009, 44, 1441-1457. [CrossRef] 
56. Chang, S.J. Determination of the optimal rotation age: A theoretical analysis. For. Ecol. Manag. 1984, 8, 137-147. [CrossRef]

57. Swift, L.W. Forest access roads: Design, maintenance, and soil loss. In Forest Hydrology and Ecology at Coweeta; Swank, W., Crossley, D., Eds.; Springer: New York, NY, USA, 1988; Volume 66, pp. 313-324.

58. Sheffield, J.; Camargo, S.; Fu, R.; Hu, Q.; Jiang, X.; Johnson, N.; Karnauskas, K.; Tae Kim, S.; Kinter, J.; Kumar, S.; et al. North American climate in CMIP5 experiments. Part II: Evaluation of historical simulations of intraseasonal to decadal variability. J. Clim. 2013, 26, 9247-9290. [CrossRef]

59. Susaeta, A.; Carter, D.; Adams, D.; Dwivedi, P. Climate change and ecosystem services output efficiency in southern natural loblolly pine forests. Environ. Manag. 2016, 58, 417-430. [CrossRef] [PubMed]

60. Susaeta, A.; Adams, D.; Carter, D.; Gonzalez-Benecke, C.; Dwivedi, P. Technical, allocative, and total profit efficiency of loblolly pine forests under changing climatic conditions. For. Pol. Econ. 2016, 72, 106-114. [CrossRef]

61. Susaeta, A.; Carter, D.; Chang, S.J.; Adams, D. A generalized Reed model with application to wildfire risk in even-aged southern United States pine plantations. For. Pol. Econ. 2016, 67, 60-69. [CrossRef]

62. Susaeta, A.; Soto, J.; Adams, D.; Hulcr, J. Pre-invasion economic assessment of invasive species prevention: A putative ambrosia beetle in Southeastern loblolly pine forests. J. Environ. Manag. 2016, 183, 875-881. [CrossRef] [PubMed]

(C) 2017 by the authors. Licensee MDPI, Basel, Switzerland. This article is an open access article distributed under the terms and conditions of the Creative Commons Attribution (CC BY) license (http:/ / creativecommons.org/licenses/by/4.0/). 